\title{
Implementation of endoscopic submucosal dissection for early upper gastrointestinal tract cancer after primary experience in colorectal endoscopic submucosal dissection *
}

\section{(ㄷ)(우우}

\author{
Authors \\ Institutions \\ 1 Department of Medicine and Gastroenterology, \\ Gemeinschaftskrankenhaus Bonn, Academic Teaching \\ Hospital, University of Bonn, Bonn, Germany \\ 2 Institute für Pathology Bonn-Duisdorf, Bonn, Germany \\ 3 Department of Endoscopy, Saku Central Hospital \\ Advanced Care Center, Saku, Nagano, Japan \\ 4 Department of General and Abdominal Surgery, \\ Gemeinschaftskrankenhaus Bonn, Academic Teaching \\ Hospital, University of Bonn, Bonn, Germany \\ 5 Division of Research and Development for Minimally \\ Invasive Treatment, Cancer Center, Keio University \\ School of Medicine, Tokyo, Japan
}

Lena Mocker ${ }^{1}$, Ralf Hildenbrand ${ }^{2}$, Tsuneo Oyama ${ }^{3}$, Bernd Sido ${ }^{4}$, Naohisa Yahagi ${ }^{5}$, Franz Ludwig Dumoulin ${ }^{1}$

submitted 11.8.2018

accepted after revision 3.12 .2018

\author{
Bibliography \\ DOI https://doi.org/10.1055/a-0854-3610 | \\ Endoscopy International Open 2019; 07: E446-E451 \\ (c) Georg Thieme Verlag KG Stuttgart · New York \\ ISSN 2364-3722
}

Corresponding author

Professor Dr. Franz Ludwig Dumoulin, Department of

Medicine and Gastroenterology,

Gemeinschaftskrankenhaus Bonn, Academic Teaching

Hospital, University of Bonn, Bonner Talweg 4-6,

D-53113 Bonn, Germany

Fax: +49-228-5081562

f.dumoulin@gk-bonn.de

\section{ABSTRACT}

Background Current guidelines recommend endoscopic submucosal dissection (ESD) as a treatment option for early cancers of the upper gastrointestinal tract with absent or minimal risk of lymph node metastasis. However, due to the low prevalence of these entities, it is difficult to achieve a competence level for ESD of upper gastrointestinal tract cancers in the Western World. Here, we present single-center data on the implementation of upper gastrointestinal ESD after previous experience with 89 colorectal ESD cases. Methods Retrospective case series of 39 consecutive patients with early cancers of the esophagus $(n=13)$ or cardia and stomach $(n=26)$ treated with ESD over a 4-year period. Results ESD was technically feasible in all cases with en bloc, R0, and curative resection rates of $100 \%, 76.9 \%$, and $71.8 \%$, respectively, and a mean procedure time of 100 minutes (30-360 minutes). After an initial 20 procedures, the R0 and curative resection rates increased from $65.0 \%$ to $89.5 \%$, and from $60.0 \%$ to $84.2 \%$, respectively. Complications were observed in four patients $(10.3 \%)$ : three perforations, one case of delayed bleeding, and one esophageal stricture. No case required emergency surgery; the 30 -day mortality rate was $0 \%$.

Conclusion In this modest case series from Europe, we observed an effectiveness and complication rate for ESD for early esophageal and gastric cancer that are comparable to other series from Europe but also to more abundant data from Asia. The results indicate that even small numbers of upper gastrointestinal cancers can be managed adequately in centers with expertise in colorectal ESD.

\section{Introduction}

The concept of organ preserving endoscopic resection for early cancers in the upper gastrointestinal tract by endoscopic submucosal dissection (ESD) has been established and validated mainly in Japan [1]. During the last decade, the concept has

\footnotetext{
* Data presented in part at the 2017 annual meeting of the German Gastroenterologists Association (Z Gastroenterol 2017; 55 (08): e57 - e299)
}

gradually been integrated into current guidelines in Western Countries [2 -7]. However, in contrast to Japan, the incidence of early cancers of the upper gastrointestinal tract in the West is relatively low $[2,6]$. Thus, since ESD is technically demanding [8], it is difficult to implement these guidelines, even in specialized centers.

In contrast to early cancers of the upper gastrointestinal tract, colorectal neoplasia is far more common, in particular, since screening programs have been implemented in many 
Western countries. In particular, the number of advanced colorectal adenomas potentially harboring high grade dysplasia or early cancer, both a potential target for ESD [9], is relatively high. However, due to the sometimes difficult access and the thin walled organ, colorectal ESD is considered even more technically demanding and prone to complications than ESD in the upper gastrointestinal tract [8]. Therefore, current guidelines see only very few, if any, exceptional indications for colorectal $\operatorname{ESD}[4,10]$. Against this mainstream, we have adopted colorectal ESD as an ongoing prospective registry in our department since 2012 [11]. Given the acquired experience in colorectal ESD, we later started with ESD in the upper gastrointestinal tract.

Here, we report a case series of 39 ESD procedures for early upper gastrointestinal tract cancers started after previous experience with colorectal ESD. The study aimed at defining the effectiveness and complication rate of ESD performed on upper gastrointestinal tract cancers in the context of experience in colorectal ESD.

\section{Methods}

\section{Study design}

This is a retrospective data analysis of consecutive ESD procedures for early cancers of the esophagus or cardia and stomach over a 4-year period.

\section{Patients and lesions}

Between January 2014 and December 2017, we performed 39 consecutive ESD procedures in 39 patients (male/female, 28:11; median age 72 years, range $47-90$ years). All patients had biopsy-proven neoplastic lesions that were deemed suitable for endoscopic resection but unsuitable for en bloc endoscopic mucosal resection. In the cases with poorly differentiated, grade 3 (G3) gastric cancer, additional biopsies were taken around the lesion to rule out diffuse cancer. The data on ESD procedures were prospectively recorded (ClinicWinData, E\&L, Erlangen, Germany).

\section{ESD training}

With the exception of patient \# 35 who was treated during clinical tutoring with Professor Oyama at our institution, a single endoscopist (F.L.D.) carried out the ESD procedures. Experience with ESD was acquired under the guidance of Japanese experts as described elsewhere [11]. In selected cases, pre-therapeutic and post-therapeutic counseling was obtained from Japanese experts (T.O., N.Y.) by exchange of endoscopic and/or histopathology images.

Before starting the first ESD procedure in the upper gastrointestinal tract, 89 colorectal ESDs had been carried out and a continuously increasing number of colorectal ESDs were performed during the study period ( $\triangleright$ Fig. 1 ). Colorectal lesions were distributed throughout the entire colon and rectum (cecum/right colon $40 \%$; left colon $9 \%$; rectum $51 \%$ ). The rate of technical feasibility was $85 \%$; the en bloc and $\mathrm{R} 0$ resection rates of these feasible colorectal procedures were $100 \%$ and $75.1 \%$, respectively.

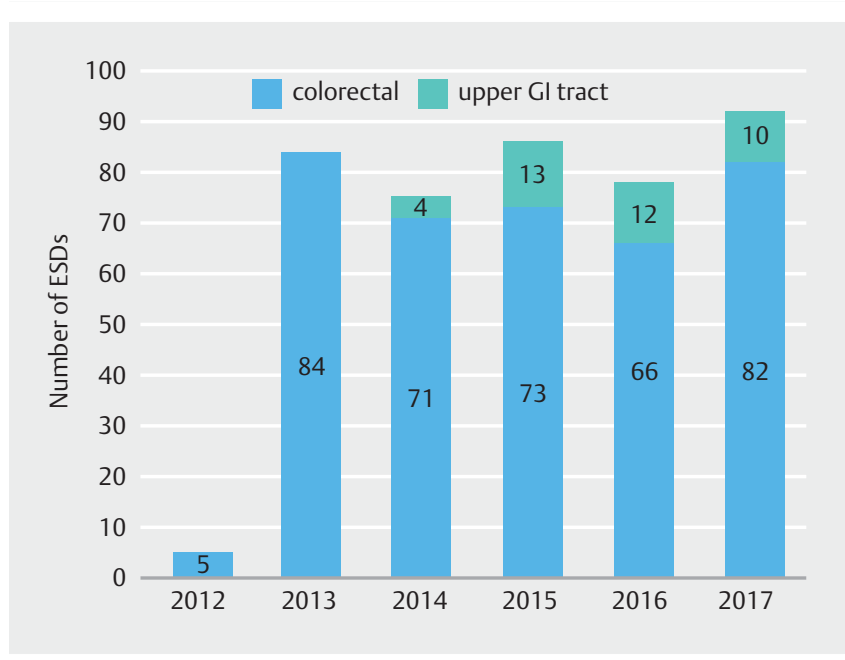

- Fig. 1 Relative caseload for colorectal endoscopic submucosal dissection (ESD) versus ESD in the upper gastrointestinal tract.

\section{ESD procedures}

ESD procedures were carried out under general anesthesia in 23/39 patients (in particular, for lesions in the esophagus/cardia but also for frail elderly patients). The remaining 16 patients were treated under conscious sedation with propofol (B, Braun Melsungen, Germany) and midazolam (Roche Pharma, Grenzach-Whylen, Germany). Definition of lateral margins and marking were carried out immediately before starting the ESD procedure using white light imaging, narrow-band imaging and chromoendoscopy ( $2 \%$ Lugol solution for squamous cell lesions, $1.5 \%$ acetic acid for lesions at the esophagogastric junction and occasionally $0.4 \%$ indigo carmine for gastric lesions). The set-up for ESD consisted of diagnostic gastroscopes with waterjet function (GIF-H180-J or GIF-HQ190), $4 \mathrm{~mm}$ straight distal attachment, water irrigation pump and carbon dioxide insufflation (all from Olympus Medical Systems, Tokyo, Japan). After endoscopic evaluation and marking of the lesion, the submucosa was injected with $4 \%$ gelatin solution (Gelafundin $4 \%$; B Braun Melsungen) with $0.01 \%$ indigo carmine added (Novaplus, Lake Forrest, Illinois, United States). ESD was carried out with dual knife (colorectal for esophageal lesions, gastric type for gastric lesions; $n=32$ ) or hook knife (in cases of difficult access or dense fibrosis; $n=7$ ) and a hemostatic forceps (all from Olympus Medical Systems) using the stepwise mucosal incision/submucosal dissection method ( Fig.2). Problems with traction were resolved using the counter-traction clip with line technique [12]. The settings of the Erbe 200S electrosurgical unit (Erbe Elektromedizin, Tübingen, Germany) were "soft coagulation" (effect 5/50 W for esophageal lesions, effect 5/80 W for gastric lesions) for initial marking of the target lesion, "EndoCut I" (effect 2, duration 3, interval 3) for mucosal incision, "forced coagulation" (effect 3/30 W) for submucosal dissection and "soft coagulation" (effect $3 / 30 \mathrm{~W}$ ) for the treatment of bleeding vessels with the tip of the knife. To prevent delayed bleeding, additional coagulation and placement of hemoclips were used on the resection bed. Clipping was also performed 

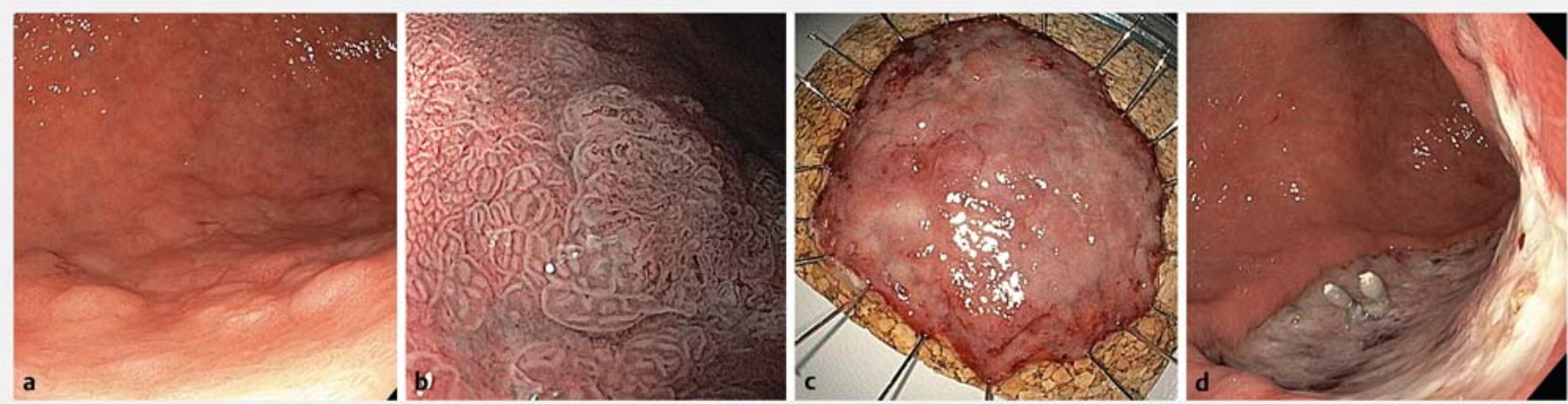

Fig. 2 Endoscopic submucosal dissection (ESD) of early gastric cancer. a Localization of a 0 - Ila/b lesion on the posterior side of the gastric body. $\mathbf{b}$ Detail of the lesion showing the lateral margin (narrow band imaging). $\mathbf{c}$ Resected specimen pinned on corkboard. $\mathbf{d}$ ESD wound on the day after the intervention showing a clear base ulcer. Final histopathology result was pT1a (m3), L0, V0, R0 - G2 (intestinal type).

to close any suspected or visible microperforations (EZ clip, Olympus Medical Systems).

\section{Histopathology}

The specimens were loosely stretched on corkboard and fixed in $4 \%$ phosphate buffered formaldehyde. Histopathology was performed taking particular care at the lateral and vertical margins to confirm a complete resection of the lesion. Curative resection of esophageal lesions was judged according to current German guidelines [6]; for gastric lesions, standard and expanded criteria were defined according to the current Japanese guidelines [1]. All patients were discussed at our weekly interdisciplinary tumor board. In cases of expanded criteria for early gastric cancer, deviation from the German guidelines [2] was discussed in detail with the patients.

\section{Post-procedural care}

Patients were fasted for 6 hours after the ESD procedure, and later on allowed a liquid diet. Control endoscopy was performed on the first post-interventional day and soft meals were allowed thereafter. Clinical and laboratory controls were carried out on the evening and on the first day after intervention and as required in cases of post-interventional complaints. All patients were kept on proton pump inhibitors for 4 weeks; in cases of microperforations, a 3-day course of antibiotics was given. The majority of patients could be discharged from hospital after 5 days. All patients were discussed at our weekly tumor board. In cases of curative resection (see below), follow-up endoscopic controls were recommended after 3 months, then 6 months, and yearly thereafter. In cases of non-curative resection, surgical resection was recommended unless the patient was unfit for surgery.

\section{Definition of outcome and complications}

We defined resection in one piece as "en bloc resection", "R0 resection" if both vertical and lateral margins were free of tumor, and "curative resection" if estimation of lymph node suggested a very low or absent risk of metastatic spread after R0 resection (favoring the criteria of the current Japanese guidelines on early gastric cancer over the more restrictive German guidelines) $[1,2,4,6]$. Perforation was diagnosed if there was clinical evidence during the procedure (i.e. transmural cut). Delayed bleeding was defined as a loss of 3 hemoglobin units any time after completion of the ESD procedure. A significant stricture was diagnosed when the patient developed dysphagia in addition to an endoscopically verified narrowing of the lumen (inability to pass a standard $10 \mathrm{~mm}$ endoscope through the stricture).

\section{Statistics}

Descriptive data analysis and graphics were performed using standard software (Microsoft Excel for Mac 2011).

\section{Results}

\section{Effectiveness}

ESD was performed on 39 consecutive malignant lesions in 39 patients (esophagus $n=13$; cardia and stomach $n=26$ ) ( $\triangleright$ Table 1). The median lesion size was $40.0 \mathrm{~mm}$ (range $16-$ $70 \mathrm{~mm}$ ), and median procedure time was 100 minutes (range 30-360 minutes). All lesions were resected en bloc. The R0 rate was $76.9 \%$ (30/39), and the rate of curative resections $71.8 \%$ (28/39) ( Table 2 ). Of note, 7/9 R1 resections were due to a positive vertical margin. Moreover, effectiveness was somewhat better for ESD on gastric lesions than on esophageal lesions. In 11 patients, additional surgery was recommended after interdisciplinary evaluation in our tumor board. Eight patients finally underwent surgery and in one of them, residual cancer was detected; lymph node metastasis was not detected in any of the operated patients. From the patients unfit for surgery, one died within 6 months from progressive esophageal cancer while the other two are alive without recurrence after 20 and 24 months, respectively. Altogether, with a median follow-up period of 8.5 months (range $2-41$ months), all patients treated endoscopically have a favorable clinical course without recurrence or metachronous cancer. 
- Table 1 Lesion characteristics.

\begin{tabular}{|c|c|c|c|}
\hline $\begin{array}{l}\text { Localiza- } \\
\text { tion }\end{array}$ & $\begin{array}{l}\text { Size, } \\
\text { median } \\
\text { (range) }\end{array}$ & $\begin{array}{l}\text { Morphology } \\
\text { (Paris classi- } \\
\text { fication) }\end{array}$ & Histology \\
\hline \multirow[t]{3}{*}{$\begin{array}{l}\text { Esophagus } \\
(n=13)\end{array}$} & \multirow[t]{3}{*}{$\begin{array}{l}39 m m \\
(21-62)\end{array}$} & $0-$ Is (5), & $\begin{array}{l}\text { Squamous cell } \\
\text { carcinoma (2), }\end{array}$ \\
\hline & & 0 - Ila (6), & $\begin{array}{l}\text { Adenocarcinoma } \\
\text { (11) }\end{array}$ \\
\hline & & $0-I I b(2)$ & \\
\hline \multirow{6}{*}{$\begin{array}{l}\text { Cardia/ } \\
\text { stomach } \\
(n=26)\end{array}$} & \multirow[t]{6}{*}{$\begin{array}{l}42 \mathrm{~mm} \\
(16-70)\end{array}$} & $0-\operatorname{lp}(1)$ & $\begin{array}{l}\text { Adenocarcinoma } \\
\text { intestinal type (20), }\end{array}$ \\
\hline & & $0-$ Is (9), & $\begin{array}{l}\text { Adenocarcinoma } \\
\text { diffuse type (5), }\end{array}$ \\
\hline & & 0 - Ila (8), & $\begin{array}{l}\text { Adeno-neuroendo- } \\
\text { crine carcinoma (1) }\end{array}$ \\
\hline & & $0-\mathrm{IIb}(3)$ & \\
\hline & & 0 - Ila/b (4), & \\
\hline & & $0-\| \mathrm{a} / \mathrm{c}(1)$ & \\
\hline
\end{tabular}

- Table 2 Outcome of 39 endoscopic submucosal dissection (ESD) procedures for upper gastrointestinal tract lesions: outcome by location.

\begin{tabular}{|c|c|c|c|}
\hline & $\begin{array}{l}\text { All lesions } \\
(n=39)\end{array}$ & $\begin{array}{l}\text { Esophagus } \\
(n=13)\end{array}$ & $\begin{array}{l}\text { Cardia/ } \\
\text { stomach } \\
(n=26)\end{array}$ \\
\hline $\begin{array}{l}\text { Size, median } \\
\text { (range), mm }\end{array}$ & $\begin{array}{l}40 \\
(16-70)\end{array}$ & $\begin{array}{l}39 \\
(21-62)\end{array}$ & $\begin{array}{l}42 \\
(16-70)\end{array}$ \\
\hline $\begin{array}{l}\text { Time, median } \\
\text { (range), min }\end{array}$ & $\begin{array}{l}100 \\
(30-360)\end{array}$ & $\begin{array}{l}100 \\
(30-180)\end{array}$ & $\begin{array}{l}100 \\
(55-360)\end{array}$ \\
\hline En bloc resection & $\begin{array}{l}39 / 39 \\
(100.0 \%)\end{array}$ & $\begin{array}{l}13 / 13 \\
(100.0 \%)\end{array}$ & $\begin{array}{l}26 / 26 \\
(100.0 \%)\end{array}$ \\
\hline R0 resection & $\begin{array}{l}30 / 39 \\
(76.9 \%)\end{array}$ & $\begin{array}{l}9 / 13 \\
(69.2 \%)\end{array}$ & $\begin{array}{l}21 / 26 \\
(80.8 \%)\end{array}$ \\
\hline Curative resection & $\begin{array}{l}28 / 39 \\
(71.8 \%)\end{array}$ & $\begin{array}{l}9 / 13 \\
(69.2 \%)\end{array}$ & $\begin{array}{l}19 / 26 \\
(73.1 \%)\end{array}$ \\
\hline Complications & $\begin{array}{l}4 / 39 \\
(10.3 \%)\end{array}$ & $\begin{array}{l}2 / 13 \\
(15.4 \%)\end{array}$ & $\begin{array}{l}2 / 26 \\
(7.7 \%)\end{array}$ \\
\hline
\end{tabular}

\section{Complications}

We experienced complications in four interventions (10.3\%). There were three microperforations (7.7\%), which could be treated conservatively. In addition, one delayed bleeding occurred in a patient on oral anticoagulation 10 days after ESD $(2.6 \%)$, and one stricture (2.6\%) was observed after a subtotal circumferential esophageal ESD, which was successfully treated by a single endoscopic balloon dilatation. There were no emergency surgical procedures. The 30 -day mortality rate was $0 \%$.
- Table 3 Outcome of 39 endoscopic submucosal dissection (ESD) procedures for upper gastrointestinal tract lesions: outcome by learning curve.

\begin{tabular}{|c|c|c|c|}
\hline & $\begin{array}{l}\text { All inter- } \\
\text { ventions }\end{array}$ & $\begin{array}{l}\text { Interven- } \\
\text { tions } \\
\# 1-20\end{array}$ & $\begin{array}{l}\text { Interven- } \\
\text { tions } \\
\# 21 \text { - } 39\end{array}$ \\
\hline $\begin{array}{l}\text { Size median } \\
\text { (range), mm }\end{array}$ & $\begin{array}{l}40 \\
(16-70)\end{array}$ & $\begin{array}{l}46 \\
(16-63)\end{array}$ & $\begin{array}{l}39 \\
(21-70)\end{array}$ \\
\hline $\begin{array}{l}\text { Time median } \\
\text { (range), min }\end{array}$ & $\begin{array}{l}100 \\
(30-360)\end{array}$ & $\begin{array}{l}100 \\
(60-360)\end{array}$ & $\begin{array}{l}100 \\
(30-180)\end{array}$ \\
\hline En bloc resection & $\begin{array}{l}39 / 39 \\
(100.0 \%)\end{array}$ & $\begin{array}{l}20 / 20 \\
(100.0 \%)\end{array}$ & $\begin{array}{l}19 / 19 \\
(100.0 \%)\end{array}$ \\
\hline R0 resection & $\begin{array}{l}30 / 39 \\
(76.9 \%)\end{array}$ & $\begin{array}{l}13 / 20 \\
(65.0 \%)\end{array}$ & $\begin{array}{l}17 / 19 \\
(89.5 \%)\end{array}$ \\
\hline Curative resection & $\begin{array}{l}28 / 39 \\
(71.8 \%)\end{array}$ & $\begin{array}{l}12 / 20 \\
(60.0 \%)\end{array}$ & $\begin{array}{l}16 / 19 \\
(84.2 \%)\end{array}$ \\
\hline
\end{tabular}

\section{Learning curve}

When comparing the results for the initial 20 ESD procedures versus the remaining 19 procedures, an increase in $\mathrm{R} 0$ and curative resection rates was evident, although this did not reach statistical significance ( $\triangleright$ Table $\mathbf{3})$.

\section{Discussion}

Initially established in Japan, ESD is now an accepted treatment option for selected early upper gastrointestinal tract cancers in Western countries [2-7]. In Asia, ESD competence is acquired by treating early gastric cancer under expert supervision. In the West, the incidence of early gastric cancer is low and the number of ESD experts is limited. Thus, it is difficult to perform the suggested minimum of tutored gastric procedures necessary to achieve a basic ESD competence $[13,14]$. On the other hand, the prevalence of colorectal lesions in Western countries is much higher. Thus, the concept of a prevalence-of-lesionsbased approach has been proposed where ESD competence is acquired on colorectal rather than gastric lesions [14-16]. Moreover, it has been demonstrated that, even with limited experience in gastric ESD, experienced endoscopists can achieve a competence level in colorectal ESD [17].

Here, we report a consecutive case series of ESD for malignant lesions of the upper gastrointestinal tract. We observed favorable en bloc, R0, and curative resection rates and an acceptable number of complications despite a low case volume. Although not statistically significant, the effectiveness of the method increased after the initial 20 ESD cases resulting in R0 and curative resection rates of $89.5 \%$ and $84.2 \%$, respectively. The results presented are unexpectedly good, given the small caseload over a 4-year period.

Although modest in comparison to the majority of studies from Asia [18], the results are comparable to published series from other European centers [19-27] ( $\triangleright$ Table 4). In addition, the data presented here (i. e. primary experience in colorectal ESD, initiating ESD for upper gastrointestinal tract cancer on 
- Table 4 Non-Asian endoscopic submucosal dissection (ESD) studies on early esophageal (E) or gastric (G) cancer.

\begin{tabular}{|c|c|c|c|c|c|c|c|c|c|c|}
\hline Study & $\begin{array}{l}\text { Proce- } \\
\text { dures } \\
\text { (n) }\end{array}$ & $\begin{array}{l}\text { Locali- } \\
\text { zation } \\
\text { (n) }\end{array}$ & $\begin{array}{l}\text { Size } \\
(\mathrm{mm})\end{array}$ & $\begin{array}{l}\text { Time } \\
\text { (min) }\end{array}$ & $\begin{array}{l}\text { En bloc } \\
\text { rate }(\%)\end{array}$ & $\begin{array}{l}\text { R0 } \\
\text { rate } \\
(\%)\end{array}$ & $\begin{array}{l}\text { Curative } \\
\text { rate }(\%)\end{array}$ & $\begin{array}{l}\text { Perfo- } \\
\text { ration } \\
\text { (\%) }\end{array}$ & $\begin{array}{l}\text { Bleed- } \\
\text { ing } \\
(\%)\end{array}$ & $\begin{array}{l}\text { Stric- } \\
\text { ture } \\
(\%)\end{array}$ \\
\hline This study (2019) & 39 & $\begin{array}{l}E(13) \\
G(26)\end{array}$ & 40 & 100 & 100 & 76.9 & 71.8 & 7.7 & 2.6 & 2.6 \\
\hline $\begin{array}{l}\text { Terheggen et al. } \\
\text { (2017) [19] }\end{array}$ & 20 & $\mathrm{E}$ & 29 & 54 & 100 & 58.8 & 52.9 & 10 & 0 & NA \\
\hline $\begin{array}{l}\text { Subramaniam et al. } \\
\text { (2017) [20] }\end{array}$ & 143 & $\mathrm{E}$ & 31.1 & 79.5 & 90.8 & 78.9 & 65.8 & 0 & 1.4 & 2.1 \\
\hline $\begin{array}{l}\text { Chevaux et al. (2015) } \\
\text { [21] }\end{array}$ & 73 & $\mathrm{E}$ & 52.5 & 117 & 90 & NA & 85 & 4 & 2.7 & 60 \\
\hline $\begin{array}{l}\text { Höbel et al. (2015) } \\
\text { [22] }\end{array}$ & 22 & $\mathrm{E}$ & 44 & 114 & 95.5 & 81.8 & 77.3 & 4.5 & 9.1 & 13.6 \\
\hline $\begin{array}{l}\text { Probst et al. (2015) } \\
\text { [23] }\end{array}$ & 111 & $\mathrm{E}$ & 38 & 142 & 96.4 & 85.6 & 66.7 & 0 & 0.9 & 11.7 \\
\hline $\begin{array}{l}\text { Repici et al. (2013) } \\
\text { [24] }\end{array}$ & 42 & G & 25 & NA & 100 & 92.8 & NA & 0 & 7.1 & 0 \\
\hline $\begin{array}{l}\text { Neuhaus et al. (2012) } \\
\text { [25] }\end{array}$ & 30 & $\mathrm{E}$ & 25 & 75 & 90 & 38.5 & NA & 0 & 6.6 & NA \\
\hline $\begin{array}{l}\text { Schumacher et al. } \\
\text { (2012) [26] }\end{array}$ & 30 & G & 25 & 74 & 90 & 64.3 & NA & 10 & 6.7 & NA \\
\hline $\begin{array}{l}\text { Probst et al. (2010) } \\
\text { [27] }\end{array}$ & 66 & G & 42 & 153 & 83.3 & 66.7 & 48.5 & 0 & 3.5 & 4.7 \\
\hline
\end{tabular}

the background of a continuously higher caseload for colorectal cases, achieving relatively good treatment outcomes despite a small caseload) seem to support the above-mentioned prevalence-of-lesions-based approach [14-16]. Thus, before initiating ESD in the upper gastrointestinal tract, we already had experience with more than 80 colorectal ESD procedures. With regard to published data on learning curves for colorectal EMR after circumferential mucosal incision and colorectal ESD [28, 29], it is reasonable to assume that some competence had been obtained before starting ESDs for upper gastrointestinal tract cancer and that this competence had a positive impact on the outcome.

Another interesting aspect of this case series relates to the fact that more than half of the early gastric cancer lesions were outside the 2011 German guidelines criteria [2]. However, these resections were within the Japanese guidelines criteria, which are supported by large patient numbers with a longterm follow-up [18]. Promising data have also been published from Germany [30]. Thus, after discussing the issue, i. e. endoscopic resection outside the current German guidelines but within Japanese criteria for curative resection, none of our patients chose to undergo additional surgery.

The data presented have obvious limitations. Thus, although the data were derived from consecutive cases, the retrospective design of the study might have impaired the data quality. Moreover, ESD procedures were carried out by a single endoscopist. The reported outcome may therefore not be represen- tative for other endoscopists with different backgrounds. Finally, in addition to technical skills acquired by colorectal ESD, access to the guidance of our Japanese mentors probably had an additional positive impact on the outcome.

In summary, we have shown promising effectiveness and safety data in a relatively small series of ESD procedures on early cancers of the upper gastrointestinal tract. The favorable results might be due to previous and continuing experience in colorectal ESD. They are in support of a prevalence-of-lesionsbased approach for Western endoscopists to acquire competence in colorectal ESD first before proceeding to perform ESDs for early upper gastrointestinal cancers.

\section{Acknowledgments}

We are deeply indebted to our referring colleagues as well as to our patients. Moreover, we gratefully acknowledge the continuous support of the GKH Endoscopy Team headed by Naile Gerikalan.

\section{Competing interests}

None 
[1] Ono H, Yao K, Fujishiro M et al. Guidelines for endoscopic submucosal dissection and endoscopic mucosal resection for early gastric cancer. Dig Endosc 2016; 28: 3-15

[2] Moehler M, Al-Batran SE, Andus T et al. [German S3-guideline "Diagnosis and treatment of esophagogastric cancer"]. Z Gastroenterol 2011; 49: $461-531$

[3] Stahl M, Mariette C, Haustermans K et al. Oesophageal cancer: ESMO Clinical Practice Guidelines for diagnosis, treatment and follow-up. Ann Oncol 2013; 24: (Suppl. 06): vi51 - 56

[4] Pimentel-Nunes P, Dinis-Ribeiro M, Ponchon T et al. Endoscopic submucosal dissection: European Society of Gastrointestinal Endoscopy (ESGE) Guideline. Endoscopy 2015; 47: 829-854

[5] Smyth EC, Verheij M, Allum W et al. Gastric cancer: ESMO Clinical Practice Guidelines for diagnosis, treatment and follow-up. Ann Oncol 2016; 27: v38-v49

[6] Porschen R, Buck A, Fischbach W et al. [German S3 guideline esophageal cancer]. Z Gastroenterol 2015; 53: $1288-1347$

[7] Shaheen N], Falk GW, lyer PG et al. ACG Clinical Guideline: Diagnosis and Management of Barrett's Esophagus. Am J Gastroenterol 2016; 111: 30 - 50; quiz 51

[8] Nishizawa T, Yahagi N. Endoscopic mucosal resection and endoscopic submucosal dissection: technique and new directions. Curr Opin Gastroenterol 2017; 33: 315-319

[9] Tanaka S, Kashida H, Saito Y et al. JGES guidelines for colorectal endoscopic submucosal dissection/endoscopic mucosal resection. Dig Endosc 2015; 27: 417-434

[10] Schmiegel W, Buchberger B, Follmann M et al. S3-Leitlinie - Kolorektales Karzinom. Z Gastroenterol 2017; 55: 1344-1498

[11] Sauer M, Hildenbrand R, Oyama T et al. Endoscopic submucosal dissection for flat or sessile colorectal neoplasia > $20 \mathrm{~mm}$ : A European single-center series of 182 cases. Endosc Int Open 2016; 4: E895 - 900

[12] Oyama T. Counter traction makes endoscopic submucosal dissection easier. Clin Endosc 2012; 45: 375 - 378

[13] Uraoka T, Parra-Blanco A, Yahagi N. Colorectal endoscopic submucosal dissection: is it suitable in western countries? J Gastroenterol Hepatol 2013; 28: $406-414$

[14] Oyama T, Yahagi N, Ponchon T et al. How to establish endoscopic submucosal dissection in Western countries. World J Gastroenterol 2015; 21: 11209-11220

[15] Wagner A, Neureiter D, Kiesslich T et al. Single-center implementation of endoscopic submucosal dissection (ESD) in the colorectum: Low recurrence rate after intention-to-treat ESD. Dig Endosc 2018; 30: $354-363$

[16] Berr F, Wagner A, Kiesslich T et al. Untutored learning curve to establish endoscopic submucosal dissection on competence level. Digestion 2014; 89: $184-193$

[17] Shiga H, Ohba R, Matsuhashi T et al. Feasibility of colorectal endoscopic submucosal dissection (ESD) carried out by endoscopists with no or little experience in gastric ESD. Dig Endosc 2017; 29: (Suppl. 02): $58-65$

[18] Nishizawa T, Yahagi N. Long-term outcomes of using endoscopic submucosal dissection to treat early gastric cancer. Gut Liver 2018; 12: $119-124$

[19] Terheggen G, Horn EM, Vieth M et al. A randomised trial of endoscopic submucosal dissection versus endoscopic mucosal resection for early Barrett's neoplasia. Gut 2017; 66: $783-793$

[20] Subramaniam S, Chedgy F, Longcroft-Wheaton G et al. Complex early Barrett's neoplasia at 3 Western centers: European Barrett's Endoscopic Submucosal Dissection Trial (E-BEST). Gastrointest Endosc 2017; 86: 608-618

[21] Chevaux JB, Piessevaux H, Jouret-Mourin A et al. Clinical outcome in patients treated with endoscopic submucosal dissection for superficial Barrett's neoplasia. Endoscopy 2015; 47: $103-112$

[22] Hobel S, Dautel P, Baumbach R et al. Single center experience of endoscopic submucosal dissection (ESD) in early Barrett's adenocarcinoma. Surg Endosc 2015; 29: 1591-1597

[23] Probst A, Aust D, Markl B et al. Early esophageal cancer in Europe: endoscopic treatment by endoscopic submucosal dissection. Endoscopy 2015; 47: $113-121$

[24] Repici A, Zullo A, Hassan C et al. Endoscopic submucosal dissection of early gastric neoplastic lesions: a western series. Eur J Gastroenterol Hepatol 2013; 25: $1261-1264$

[25] Neuhaus H, Terheggen G, Rutz EM et al. Endoscopic submucosal dissection plus radiofrequency ablation of neoplastic Barrett's esophagus. Endoscopy 2012; 44: 1105-1113

[26] Schumacher B, Charton JP, Nordmann T et al. Endoscopic submucosa dissection of early gastric neoplasia with a water jet-assisted knife: a Western, single-center experience. Gastrointest Endosc 2012; 75: $1166-1174$

[27] Probst A, Pommer B, Golger D et al. Endoscopic submucosal dissection in gastric neoplasia - experience from a European center. Endoscopy 2010; 42: $1037-1044$

[28] Choi IJ, Kim CG, Chang HJ et al. The learning curve for EMR with circumferential mucosal incision in treating intramucosal gastric neoplasm. Gastrointest Endosc 2005; 62: 860-865

[29] Hotta K, Oyama T, Shinohara T et al. Learning curve for endoscopic submucosal dissection of large colorectal tumors. Dig Endosc 2010; 22: $302-306$

[30] Probst A, Schneider A, Schaller T et al. Endoscopic submucosal dissection for early gastric cancer: are expanded resection criteria safe for Western patients? Endoscopy 2017; 49: 855-865 